\title{
ROOT CAUSE ANALYSIS FOR CONDUCTING UNIVERSITY'S COMMUNITY SERVICE TO MICRO AND SMALL FIRMS
}

\author{
Sri Maryanti ${ }^{1}$, Afred Suci ${ }^{2 *}$, Nining Sudiar ${ }^{3}$, Hardi Hardi ${ }^{4}$ \\ 1,4 Department of Management, Universitas Lancang Kuning, Indonesia \\ ${ }^{2}$ Department of Business and Administration, National Taiwan University of Science and Technology, Taiwan \\ ${ }^{3}$ Department of Library Science, Universitas Lancang Kuning, Indonesia

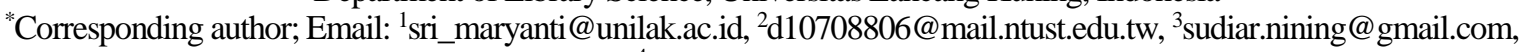 \\ hhardi@unilak.ac.id
}

\begin{abstract}
The study aimed to identify the root problems facing by the small firm that further can guide the university's community service program to implement the most appropriate treatments to enhance the partnering small firm's business performance. A qualitative approach was employed, primarily conducting in-depth interviews and brainstorming with business owners, employees, store managers, and consumers of "Wajik Tapai" in Riau Province, in the framework of root cause analysis. The result revealed that the distinct causes identified as the driver of the small firm's income stagnation could be rooted in four perspectives, i.e., product durability, non-ergonomic working layout with a traditional process, conventional/offline marketing, and variability of product.
\end{abstract}

Keywords: Small business, root cause analysis, university, community service.

\section{Introduction}

What is your real problem? Ideally, such a question should be deeply explored - in the first place - from the micro and small businesses while conducting a situation analysis for the community service program. Ironically, often in analyzing the situation of the prospective partners, the lecturers are just framing the situation to match their abilities and expertise. Consequently, the treatment assisted to the partner is not precisely relevant to enhance the micro and small firm's business performance.

Micro and small businesses are the greatest in the number of enterprises in several countries (Boldrini, Caverot, \& Ezequel, 2017). For instance, in Indonesia, mainly, the SME's occupy $99 \%$ of the business population and absorb 97\% of the workforce (Suci, 2017). Within the process, Indonesian's small businesses encounter various kinds of obstacles. Stereotypical barriers facing SMEs are mostly about capital, technology, marketing, production quality, and low human resources (Daengs GS et al., 2019; Wijaya, Nurhadi, \& Kuncoro, 2017). Moreover, external support from other parties also becomes a big challenge (Hatta, Riskarini, \& Ichwan, 2018). For this reason, the Higher Education Institution (HEI), as the source of knowledge, skill, and technology, is expected to deliver significant contributions to the development of the business community, including SMEs. HEI and SME's alliance allows the transfer of knowledge, technology, and innovation
(Forsman, 2011; Boldrini et al., 2017) to provide appropriate business supports (Wade \& Demb, 2009).

Meanwhile, the business sectors that are widely chosen by SMEs actors are culinary because it is one of the basic human needs (Zuari, Widayani, \& Daniel, 2013), especially the traditional food based on local potentials. Syuhada (2014) found that food businesses can help governments reduce the unemployment rate and absorb the local workforce as well as increase the community's income. These reasons lead many HEIs to choose this sector to be their partners in community service programs.

Regarding the community service program, a clichéd barrier facing tertiary institutions is short of funding (Noor, 2010; Puukka \& Marmolejo, 2008), budget reduction (Mitchell, Leachman, \& Masterson, 2016), and the rigidity of government regulations (Moeliodihardjo, Soemardi, Brodjonegoro, \& Hatakenaka, 2012), resulting universities are rarely involved in SMEs empowerment programs by the government (Puukka \& Marmolejo, 2008). Accordingly, HEIs should plan carefully when partnering with SMEs to ensure their limited funds are effectively used and able to improve small firm's performance. One possible solution is applying root cause analysis (RCA) approach as an initial phase of the business support. It is critical due to the failure of many business support programs employed (Ferreira, Strydom, \& Nieuwenhuizen, 2010) primarily caused by the university's misunderstanding of what SMEs really 
need. Frequently, disharmony occurs when HEI's contribution is different from the actual need of small firms (Breen \& Bergin-Seers, 2002), leading to an inefficient and ineffective mentoring budget.

Government and corporation perspectives, particularly those related to Corporate Social Responsibility (CSR) program, dominated most studies of assisting small businesses (e.g., Piza et al., 2016; Munro, 2017; Shamsuddin, Minai, Md. Zain, \& Al Idrus, 2020; Mulyati \& Utami, 2019; Sugiarto, Sulaiman, \& Sari, 2019), whereas HEI assisting small businesses' perspective has rarely been observed. Moreover, no studies have been conducted on HEI using the RCA approach when providing a business assistance program to small firms. Thus, the current study aimed to identify the root problem of a small business using the RCA approach by taking an example of a traditional sweet snack small manufacturer in Riau Province. This effort will make it easier for HEI to determine the most appropriate treatments for small businesses' actual problems.

Many small firm owners look for external assistance in the form of marketing, finance, and human resources (Ferreira et al., 2010). Farther barriers observed with a small business are the lack of skills and mastery of the quality of marketing, production, and business management (Fausiah, 2016). These barriers lead to the need for external assistance, not only from government and corporation but also from HEI. Assistance refers to the attempt of an individual or accompanying institution to support other individuals and community groups without profit expectations (Nufus, Iskandar, \& Senjiati, 2017). Nevertheless, assistance alone will not guarantee the success of a firm's performance (Ferreira et al., 2010); it needs a planned and measurable assistance method with the ability to enrich the product, quality, and marketing expansion required by the SMEs. The main key to the whole process is initiated by problem mapping.

Problem identification is part of the problemsolving process, which refers to a cognitive operation of the brain searching solution to identify problems or find the path to reach a goal (Wang \& Chiew, 2010). A classic theory introduced by Polya (1954) also demonstrated that problem-solving stages start with understanding the real problem, or as studied by Chou (2018), the process initiates the question: "what is the business problem?" Problem-solving might be categorized as "problem-centered," which is an effective way to solve the issues foreseen (Yeager et al., 2016). Meanwhile, the knowledge of the problem can be acquired through exploratory methods, such as observation, ethnographic studies, or in-depth interviews. Through the problemframing phase, then, the agent (small firm and HEI) gains an open mind and explores distinct alternatives to define the scope of the problem (Sarooghi, Sunny, Hornsby, \& Fernhaber, 2019). The complete solution can only start working effectively once the root of the problem has been identified (Dorst, 2011). Also, the problem requires deconstruction (Hekkert \& Van Dijk, 2011) before it can refer to a particular solution.

Like the other global small businesses throughout the world, small firms in Indonesia suffer various obstacles. Typical barriers encountering SMEs are mostly about capital, technology, marketing, production quality, and human resources (Daengs GS et al., 2019). These problems are still normative, whereas the rooting problem stage demands precise identification of the real root causes to offer relevant treatment solutions. Moreover, each industry has its symptoms, peculiarities, and challenges; hence the strategy might vary across sectors. This study surely cannot include all industry problems; thus, this study chose one industry that is geographically close but still has the unique selling point of local economic development. As stated by Qiu, Liu, and Gao (2017), the collaboration between HEIs and the local business community has shown a more significant positive impact on firm innovation. Every company has its problems, which is obviously cannot be entirely included by a single study. Therefore, a small manufacturer of traditional "Wajik Tapai" in Riau Province was selected as the study's partner.

Like any other small enterprise, the selected small firm also encounters many challenges that require problem mapping. Based on the initial observation of the firm, the study found that the company owner's main obstacle was the slow growth in revenue over the last few years (Figure 1). In business terminology, this phenomenon is called income stagnation.

Epistemologically, business income refers to any income generated as a result of an entity's operations, which is calculated as its revenue from all sources minus all business's costs (Tuovila, 2020). Meanwhile, stagnation reflects a situation in an economy when total output is either declining, flat, or growing slowly (Chappelow, 2019). Thus, by combining these two terms, the study defines income stagnation as the situation reflecting the firm's business revenue's slow or flat growth. There are many possible causes of income stagnation. From the perspective of macroeconomics, the drivers can be taxation, policy, competition, market structure, GDP growth, or demand and supply. From the aspect of microeconomics, consumer and corporate behavior can be the antecedents. Both perspectives will further influence the SMEs' performance (Lopes, Hamdok, \& Elhiraika, 2017; Lin \& Magnago, 2017; Rusu \& Roman, 2016). 


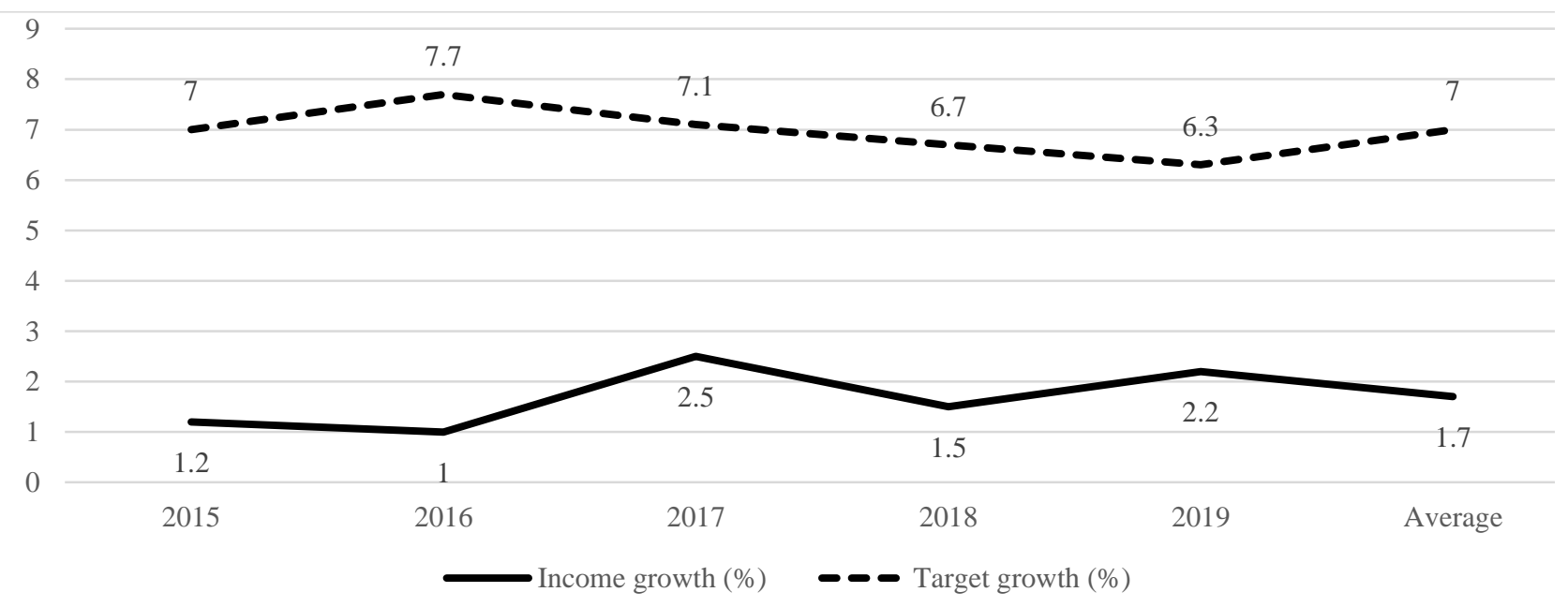

Figure 1. The income growth of the partnering firm

Those multi-aspect drivers are obviously too wide to observe by a single study; thus, to identify the root problems of the observed small firm's income stagnation, the authors limited the perspective sources from the business owner, distributors/resellers, and the consumers. Therefore, the study proposes a single research question:

$R Q$ : What is the root problem(s) causing the firm's income stagnation?

\section{Research Methods}

\section{The Partnering Firm}

The study was carried out at one small manufacturer of traditional sweet snack called "Wajik Tapai" in Riau Province, Indonesia. The primary reason for choosing this small firm was the product uniqueness by using local raw materials. Moreover, the firm's traditional product has a strong Melayu heritage symbol in Riau Province, requiring efforts to support the product.

\section{Procedure}

The study aimed to seek the root problems encountered by the firm using a qualitative approach, namely, in-depth interview, field observation, and root cause analysis (RCA). An in-depth interview was employed to explore the insights of the interviewees. Five to seven semi-structured questions were asked to 13 interviewees (see Table 1), mainly to address the firm profile, business scale, product variety, quality, production process, and the marketing approach. The entire transcript was selected, categorized, analyzed, synthesized, and placed in the result section as indirect and narrative explanations of interviewees. Because of the interviewees' open answers, the authors conducted the word categorization technique, which refers to the process of classifying words into a particular category or relevant categories, where the words are categorized based on their semantic relations (Jo, 2016). All words or sentences were analyzed for the meaning similarity and further grouped as one. For example, interviewee-1 answered: "bad wrapping"; interviewee-2: "the packaging is not attractive"; interviewee-3: "the packaging is easy to rip"; thus, those three answers would be categorized as "low-quality packaging."

The second technique was conducting field observation, in which the authors directly observed the process, including raw material handling, dough processing, moulding, wrapping, storing, distribution, and the marketing method. All field findings were documented, analyzed, and cross-validated with the interview results to check for consistency. The final step was executing RCA, which refers to a structured approach to identify causes on one or more undesired occasions or outcomes. According to Chandler (2004), the steps of RCA are identifying and defining the unwanted situation or outcome $\rightarrow$ collecting data $\rightarrow$ locating the occasions and conditions in the event and causal factor table and continuing the question "why" to obtain the most critical causes. The authors and interviewees carried out a series of brainstorming to find the root causes of the firm's problems. A fault diagram was created initiating with the end failure (income stagnation) and continuously tracing each origin that led to the prior cause. The process continued until the trail could be traced back no further. Only the contributing causes retained, and all noncontributing causes were discarded. 
Table 1

Interview Process

\begin{tabular}{|c|c|c|c|c|}
\hline Source & Location & Method & Duration & Language \\
\hline Owner & Workshop & Face-to-face & 46 minutes & Indonesian \\
\hline Production staff-1 & Workshop & Face-to-face & 14 minutes & Indonesian \\
\hline Production staff-2 & Workshop & Face-to-face & 12 minutes & Indonesian \\
\hline Quality Control & Workshop & Face-to-face & 16 minutes & Indonesian \\
\hline Marketing staff & Workshop & Face-to-face & 19 minutes & Indonesian \\
\hline Store-1 & Store & Face-to-face & 25 minutes & Indonesian \\
\hline Store-2 & Store & Face-to-face & 18 minutes & Indonesian \\
\hline Store-3 & Store & Face-to-face & 23 minutes & Indonesian \\
\hline End-consumer-1 & Store & Face-to-face & 4 minutes & Indonesian \\
\hline End-consumer-2 & Store & Face-to-face & 6 minutes & Indonesian \\
\hline End-consumer-3 & Store & Face-to-face & 6 minutes & Indonesian \\
\hline End-consumer-4 & Store & Face-to-face & 5 minutes & Indonesian \\
\hline End-consumer-5 & Store & Face-to-face & 4 minutes & Indonesian \\
\hline
\end{tabular}

\section{Finding}

The study carried out in-depth interviews with the business owner, production and marketing staff, stores, and end consumers to achieve a thorough problem perspective. Figure 2 demonstrates diverse problems from the interviewees. The issues were relevant to each other; hence causal relationships were also observed. Therefore, it is necessary to seek the root causes to identify the real source of the problems. However, the aspects of wage and capital were excluded from the RCA analysis since this study emphasized non-financial barriers such as knowledge, technology transfer, and new production methods. The entire interviewees' comments then depicted in mind map lines displaying the causal relationships between the issues (Figure 3). Also, the theoretical implications were discussed along with the discussion of the results.

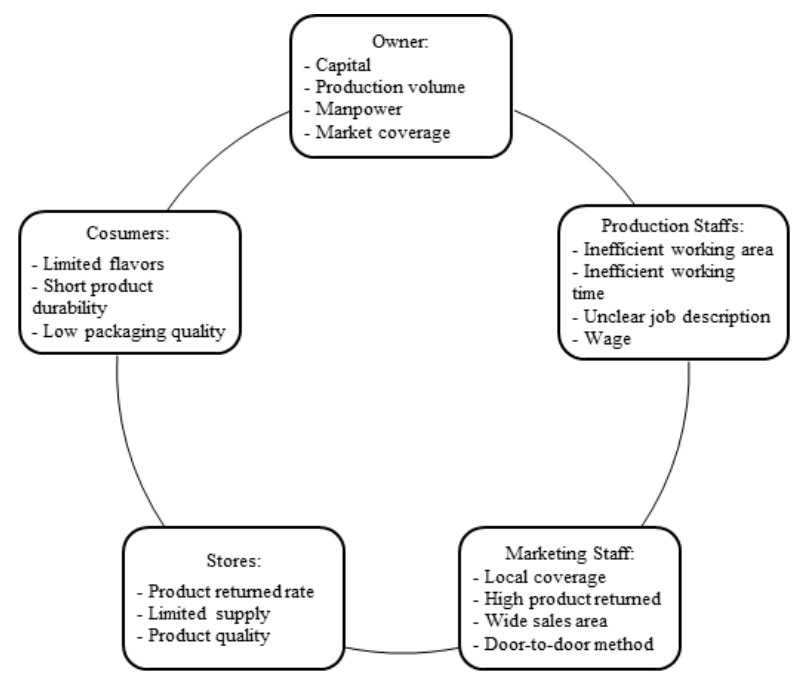

Figure 2. Problem mapping

\section{Low Product Durability}

The primary undesired outcome was the income stagnancy caused by the high monthly rate of product returned. Product returned rate turnover could achieve $20-25 \%$. The product returned were considered as trashes, giving loss to the firm. The return rate also indicates problems in the finished product quality. From the interview results, the expiration period should be three months; however, the products started becoming hard and inconsumable only in the first month. Thus, it can be concluded that the root cause of the high rate of product returned is the low durability of the product.

The finding is relevant to Hartini (2012) who stated that one of measurement tool for product quality is product durability, which can be examined through technical process point of view or by consumer's perspective. Enhancement innovation of product life cycle will improve the product quality that eventually will boost the firm's performance. Similarly, Iraldo, Facheris, \& Nucci (2017) stated that extended life cycle of a product may lead to environmental advantages. Furthermore, the more durable product frequently causes a lower cost for the consumer, save resources and reduce product wasted. From the marketing point of view, more durable products are practically always the preferred choice for the consumers, for example, the product can be used as a souvenir for out of town, out of the country or just stored longer in the freezer.

\section{Non-ergonomic Production Layout and Traditional Process}

The second antecedent of income stagnancy was the tight supply to the stores. The store owners explained that the demand for the product was relatively high, but the supplier was unable to supply consumers' demand. 


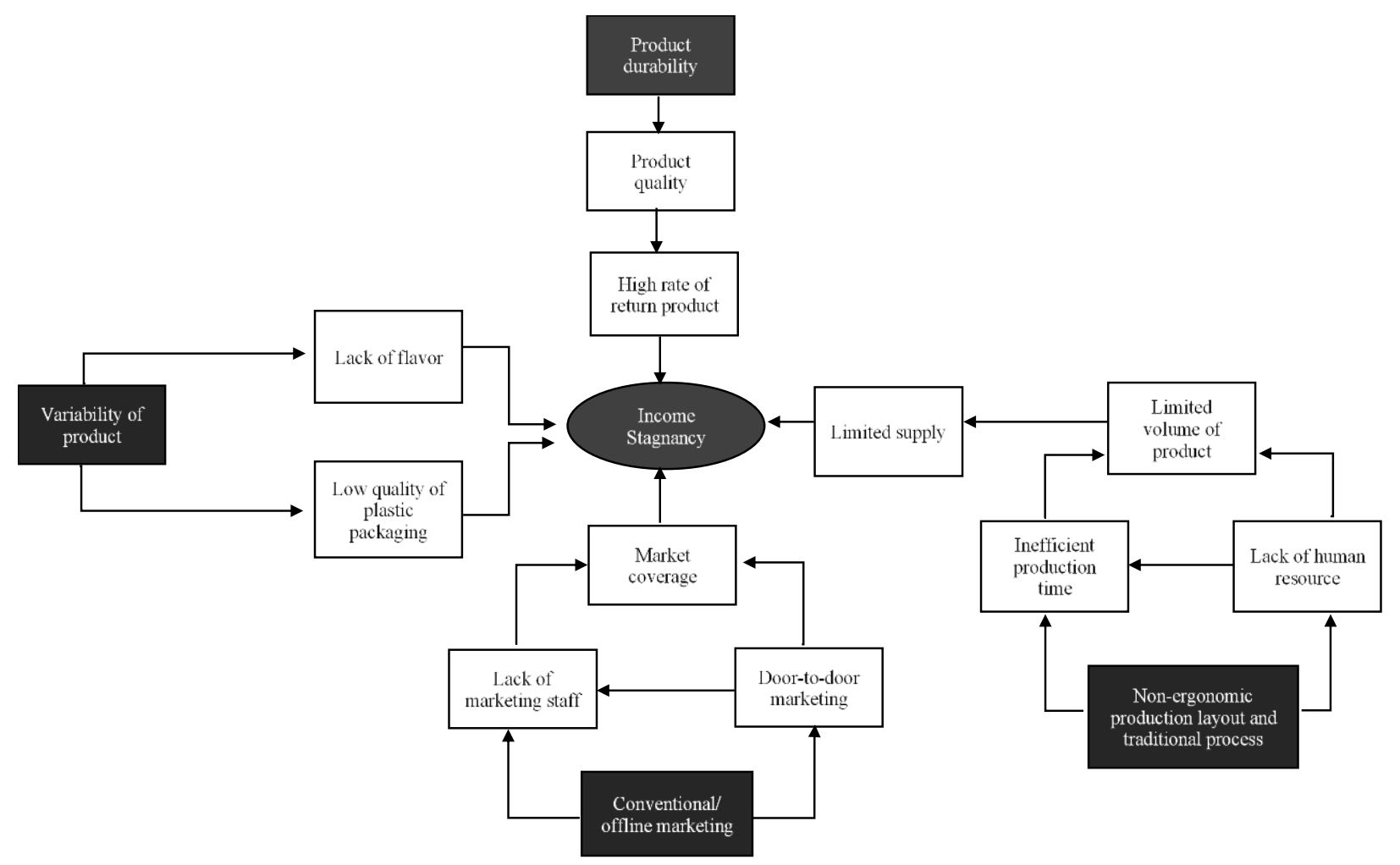

\section{Figure 3. RCA lines}

The study also found inefficiencies in production time, such that with total workers of only twelve females, making the production process relatively slow. The entire process, starting from preparation, processing raw materials, cooking, and up to packaging, was carried out using manual method. For instance, only six $\mathrm{kg}$ of dough could be manually stirred a day (Appendix A). Also, there were overlapping functions due to undefined job descriptions for each staff. What made it worse was the working layout (illustrated in Figure 4), which was not well organized, which led to the overlapping of the production and stacking areas. Therefore, it can be affirmed that the root causes of the second problem include non-ergonomic layout and manual production processes.

Ergonomics defined as a set of practices aimed at designing the working and living conditions for human use; it is a branch of science that is concerned with increasing employee productivity (Korkmaz, Alsu, Ozceylan, \& Weber, 2019). The inappropriate ergonomic layout and traditional process in the production line can cause labor shortage conditions; it will be worse if there is no clear job description following the production process flow. Non-ergonomic layouts and lack of workers cause inefficient production time, resulting in the under-targeted production. This condition further leads to a low volume of the finished product to be supplied to the stores.

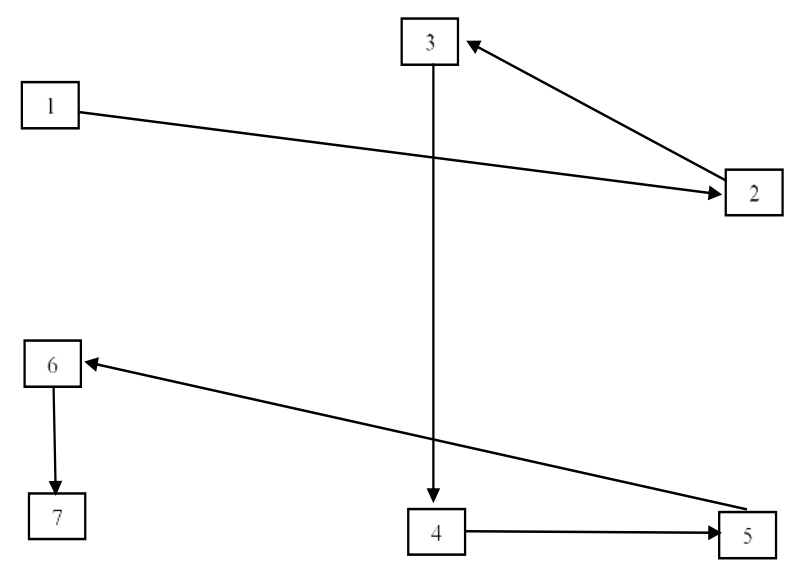

1. Raw material storage

2. Raw material mixing

3. Dough cooking (human-stirred process)

4. Product molding

5. Wrapping

6. Quality control

7. Finished product storage

Figure 4. Current working layout of the partnering firm

Less supply of merchandise is ultimately a factor in the occurrence of income stagnancy. This logic aligns with Dey, Dey, and Sharma's finding (2017), concluding that ergonomic arrangement, other than as workplace 
safety tool, would be advantageous to improve work efficiency and productivity. A proper ergonomic function and job description setting will lead to employee productivity, symbolizing workers' production efficiency in a certain period, and manifesting the workers' ability and efficiency in the production process (Liu, 2019). For the firm, effective ergonomic will save the total cost of production, and enhance the profitability rate, although the operating income remains constant (Korkmaz et al., 2019).

\section{Conventional / Offline Marketing}

The third factor of income stagnancy was the vast potency of market coverage. In contrast, the firm only had one salesperson with the ability to market the products using the door-to-door approach. The owner was aware of the production volume constraint and decided not to satisfy a potentially greater demand due to the limited production capacity. It means there was no idle capacity to be optimized to meet the demand. Besides, the marketing strategy was also traditional and offline. Therefore, the root cause detected was the conventional-offline marketing process, which led to the inability to expand the market area.

Door-to-door marketing is a conventional marketing practice that micro and small firms commonly conduct driven by the limitations of its limited distribution infrastructure (Gyanwali \& Bunchapattanasakda, 2019). Door-to-door marketing might benefit from maintaining a close relationship with the consumers/ complaints (Pratama, 2017). However, it also has some weaknesses, such as limited sales coverage area, and it requires many salespersons. The shortcoming of the number of salespeople to execute door-to-door and face to face (offline) marketing is a common problem faced by micro and small firms where the product cannot be widely recognized, ultimately leading to the limited potential income for the company (Umbara \& Hikmatyar, 2020).

\section{Variability of Product}

The interview results also revealed that the products had a limited variety of flavors. There were only four flavors, included pandan, pineapple, purple cassava, and vanilla, which were acknowledged by owners to satisfy the adult consumers but barely consumed by the younger segment. Furthermore, another shortcoming was the unattractive packaging of the product. The use of transparent white plastic as the packaging made it apparent the firm had not used packaging as a promotional strategy (Appendix B). Packaging used merely as product wrapper. Therefore, the root cause identified from these problems is the product variability.

In general, the limited variations referred to in this study are the product flavor and packaging. Packaging acts as diverge functions, and it affects how consumers respond to assorted product offerings and further substantially influences the consumer's intention to purchase (Kampfer, Leischnig, Ivens, \& Spence, 2017). As posited by Westerman et al. (2012) and Meernik et al. (2018), packaging projects a visual cue of the product, which can further influence consumers' product perception. As a result, since packaging triggers the first impression of the consumers, it should have an attractive design and, at the same time, can reflect product safety guarantee to be consumed. Moreover, sweet snack products by small businesses are often less innovative in terms of flavor (Pratama, 2017), whereas flavor evaluation significantly influences consumer's desire to buy and willingness to pay (Kampfer et al., 2017). Based on these findings, the problems causing the income stagnancy for the firm are lack of flavor and low-quality packaging, which can be further rooted in product variability as the primary problem.

From the management perspective, the findings implicate the need for root cause analysis to explore the root problems facing small businesses. By knowing the core problem, the given treatment will be precise to enhance the small businesses' performance. Besides, the application of RCA can lead the university's community service program to be efficient and provide real benefits for small businesses.

\section{Conclusion}

The most undesired outcome for many small firms is income stagnation. The various problems and causes identified to be the driver of the small firm's income stagnation in this study can be rooted into four perspectives, i.e., product durability, non-ergonomic working layout and traditional process, conventional/offline marketing, and variability of product. Thus, these four root problems should be the university's primary focus to offer appropriate treatments in the future. Not like the government and corporation who can financially support the small firms, the university should focus on the knowledge, skill, and technology transfer, which obviously can be achieved effectively only if the primary needs of the small firms are known. Hence, a root cause analysis is a highly essential step for university when initiating a community service program for small firms. 


\section{References}

Boldrini, J. C., Caverot, G., \& Ezequel, M. (2017). The journey in open innovation to develop a SME: A longitudinal case study in a French robotics company. Available at https://halshs.archives-ouver tes.fr/halshs-01502720.

Breen, J., \& Bergin-Seers, S. (2002). The small business assistance dilemma: Is the disparity between the offerings of support agencies and the needs of businesses irreconcilable. Small Enterprise Research, 10(1), 49-58. https://doi.org/10.5172/ser.10.1.49.

Chandler, F. (2004). Using root cause analysis to understand failures and accident. Washington DC.

Chappelow, J. (2019). Stagnation. Retrieved from https://www.investopedia.com/terms/s/stagnation. asp

Chou, D. C. (2018). Applying design thinking method to social entrepreneurship project. Computer Standards \& Interfaces, 55, 73-79.

Daengs G.S, A., Kurniasih, N., Reni, A., Istanti, E., Zuhroh, D., \& Qomariah, N. (2019). The effect of business sphere on competitive advantage and business performance of SMEs. Management Science Letters, 9(8), 1153-1160. doi: http://dx.doi. org/0.5267/j.msl.2019.4.025

Dey, N. C., Dey, S. C., \& Sharma, G. D. (2017). Importance of ergonomic application for the improvement of coal productivity in mines. Proceedings of the 17th Coal Operators' Conference, Mining Engineering.

Dorst, K. (2011). The core of 'design thinking' and its application. Design Studies, 32, 521-532.

Fausiah, S. (2016). Efektivitas pembinaan usaha industri kecil olahan pangan oleh Dinas Koperasi UMKM Perindustrian dan Perdagangan Kabupaten Sigi (Studi di Kecamatan Sigi Biromaru). E-Jurnal Katalogis, 4(1), 68-81.

Ferreira, E., Strydom, J., \& Nieuwenhuizen, C. (2010). The process of business assistance to small and medium enterprises in South Africa: Preliminary findings. Journal of Contemporary Management, 7(1), 94-109.

Forsman, H. (2011). Innovation capacity and innovation development in small enterprises. A comparison between the manufacturing and services sectors. Research Policy, 40(5), 739-750.

Gyanwali, S., \& Bunchapattanasakda, C. (2019). Application of entrepreneurial marketing in micro, small and medium enterprise in Dhaulagiri, Nepal. Open Journal of Business and Management, 7(2), 693708. DOI: 10.4236/ojbm.20 19.72047
Hartini, S. (2012). Peran inovasi: Pengembangan kualitas produk dan kinerja bisnis. Jurnal Manajemen dan Kewirausahaan, 14(1), 82-88. https://doi.org/10.97 44/jmk.14.1.83-90

Hatta, I. H., Riskarini, D., \& Ichwani, T. (2018). SME business development strategy: SWOT and EFEEFI analysis. Journal of Applied Management, 16(3), 537-543. http://dx.doi.org/10.21776/ub. jam. 2018. 016.03.19

Hekkert, P., \& Van Dijk, M. B. (2011). Vision in design: A guidebook for innovators. Amsterdam: BIS Publishers.

Iraldo, F., Facheris, C., \& Nucci, B. (2017). Is product durability better for environment and for economics efficiency? A comparative assessment applying LCA and LCC to two energy-intensive products. Journal of Cleaner Production, 140, 1353-1364.

Jo, T. (2016). Encoding words into string vectors for word categorization. Proceedings of the 2016 International Conference on Artificial Intelligence (ICAI).

Kampfer, K., Leischnig, A., Ivens, B. S., \& Spence, C. (2017). Touch-flavor transference: Assessing the effect of packaging weight on gustatory evaluations, desire for food and beverages, and willingness to pay. PLoS ONE, 12(10), 1-17.

Korkmaz, I. H., Alsu, E., Ozceylan, E., \& Weber, G. W. (2019). Job analysis and time study in logistic activities: A case study in packaging and loading process. Central European Journal of Operation Research, 28, 733-760.

Lin, J., \& Magnago, F. H. (2017). Electricity markets: Theories and applications. Somerset: John Wiley $\&$ Sons.

Liu, S. (2019). Research on the influencing factors of labor productivity in Northeast China. Proceedings of the 2019 4th international conference on Financial Innovation and Economic Development (ICFIED 2019).

Lopes, C., Hamdok, A., \& Elhiraika, A. (2017). Macroeconomic policy and pathways to structural transformation of African Economics. In C. Lopes, A. Hamdok, \& A. Elhiraika, Macroeconomic Policy Framework for Africa's Structural Transformation (pp. 263-280). Palgrave Macmillan, Cham.

Meernik, C., Ranney, L. M., Lazard, A. J., Kim, K., Queen, T. L., Avishai, A., Boynton, M. H., Sheeran, P. J., \& Goldstein, A. O. (2018). The effect of cigarillo packaging elements on young adult perceptions of product flavour, taste, smell, 
and appeal. PLoS ONE, 13(4), 1-13. https://doi. org/10.1371/journal.pon e.0196236

Mitchell, M., Leachman, M., \& Masterson, K. (2016). Funding down, tuition up - State cuts to higher education threaten quality and affordability at public colleges. Center on Budget and Policy Priorities. Retrieved from www.cbpp.org.

Moeliodihardjo, B. Y., Soemardi, B. W., Brodjonegoro, S. S., \& Hatakenaka, S. (2012). University, industry, and government partnership: Its present and future challenges in Indonesia. Procedia Social and Behavioral Sciences, 52, 307-316.

Mulyati, T., \& Utami, S. B. (2019). Penguatan usaha kecil menengah melalui program tanggung jawab sosial perusahaan (Studi pada PT. INKA Persero). Jurnal Ekonomi dan Manajemen, 2(2), 116-137. http://doi.org/10.25273/capital.v2i 2.3986

Munro, E. (2017). Building soft skills in the creative economy: Creative intermediaries, business support and the 'soft skills gap'. Poetics, 64, 14-25. http://dx. doi.org/10.1016/j.poetic.2017.07.002

Noor, I. H. M. (2010). Penelitian dan pengabdian masyarakat pada perguruan tinggi. Jurnal Pendidikan dan Kebudayaan, 16(3), 285-297.

Nufus, K., Iskandar, R., \& Senjiati, I. H. (2017). Efektivitas pendampingan usaha mikro kecil dan menengah syariah dalam peningkatan kesejahteraan pelaku usaha. Prosiding Keuangan dan Perbankan Syariah, 3(2), 644-652.

Piza, C., Cravo, T. A., Taylor, L., Gonzales, L., Musse, I., Furtado, I., \& Sierra, A. C. (2016). The impact of business support services for small and medium enterprises of firm performance in low- and middle-income countries: A systematic review. Campbell Systematic Review, 12(1), 1-167. DOI: https://doi.org/10.4073/csr.2016.1

Polya, G. (1954). Patterns of plausible inference. Princeton, NJ: Princeton University Press.

Pratama, T. I. (2017). Perencanaan strategis pemasaran pada perusahaan Tigor. PERFORMA, 2(2), 171182.

Qiu, S., Liu, X., \& Gao, T. (2017). Do emerging countries prefer local knowledge or distant knowledge? Spillover effect of university collaborations on local firms. Research Policy, 46(7), 1299-1311. DOI: 10.1016/j.respol.2017.06.0 01

Puukka, J., \& Marmolejo, F. (2008). Higher education institutions and regional mission: Lesson learnt from the OECD review project. Higher Education Policy, 21, 217-244.
Rusu, V. D., \& Roman, A. (2016). The impact of macroeconomic conditions on SMES performance in terms of employment. Revista Economica, 68(3), 142-159.

Sarooghi, H., Sunny, S., Hornsby, J., \& Fernhaber, S. (2019). Design thinking and entrepreneurship education: Where are we, and what are the possibilities? Journal of Small Business Management, 57(S1), 78-93. https://doi.org/10. 1111/jsbm.12541

Shamsuddin, J. B., Minai, M. S. B., Md. Zain, A. Y. B., \& Al Idrus, S. (2020). Relationship of perception and awareness towards utilization of government business support services (GBSS) in Malaysian SMES perspective. Journal of Entrepreneurship Education, 23(1), 1-12.

Suci, A. (2017). Importance performance analysis pelaku usaha UKM sektor kuliner di Pekanbaru. Jurnal Ilmu Komputer dan Bisnis, 9(1), 18321840.

Sugiarto, M., Sulaiman, A. I., \& Sari, L. K. (2019). Pendampingan corporate social responsibility (CSR) untuk penguatan usaha kecil kambing di Kabupaten Cilacap: Studi kasus CSR PT. Holcim pada Kelompok Kambing Menda Sejahtera. Prosiding Pengembangan Sumberdaya Perdesaan dan Kearifan Lokal Berkelanjutan IX, Purwokerto (pp. 655-660).

Syuhada, S. (2014). Analisis perkembangan unit usaha dan penyerapan tenaga kerja serta pengaruhnya terhadap pendapatan keluarga pada usaha mikro, kecil, dan menengah berbasis pangan olahan di Kecamatan Pelayangan Kota Jambi. Humaniora, 16(1), 23-28.

Tuovila, A. (2020). Business income. Retrieved from https://www.investopedia.com/terms/b/business income.asp

Umbara, D. S., \& Himatyar, M. (2020). Pengembangan pemasaran kopi Galunggung menggunakan system e-commerce. Mimbar Agribisnis, 6(1), 178-189.

Wade, A., \& Demb, A. (2009). A conceptual model to explore faculty community engagement. Michigan Journal of Community Service Learning, 15(2), 516.

Wang, Y., \& Chiew, V. (2010). On the cognitive process of human problem solving. Cognitive System Research, 11, 81-92.

Westerman, S. J., Gardner, P. H., Sutherland, E. J., White, T., Jordan, K., Watts, D., \& Wells, S. (2012). Product design: Preference for rounded versus angular design elements. Psychology \& Marketing, 29(8), 595-605. https://doi.org/10 $.1002 /$ mar.20546. 
Wijaya, T., Nurhadi, \& Kuncoro, A. M. (2017). Exploring the problems faced by practitioners of micro, small and medium enterprises (MSMEs) in Yogyakarta. Jurnal Manajemen dan Kewirausahaan, 19(1), 38-45. https://doi.org/1 0.9744/jmk. 19.1.38-45

Yeager, D. S., Romero, C., Paunesku, D., Hulleman, C. S., Schneider, B., Hinojosa, C., Lee, H. Y., O'Brien, J., Flint, K., Roberts, A., Trott, J., Greene, D., Walton, G. M., \& Dweck, C. S. (2016). Using

\section{Appendix A.}

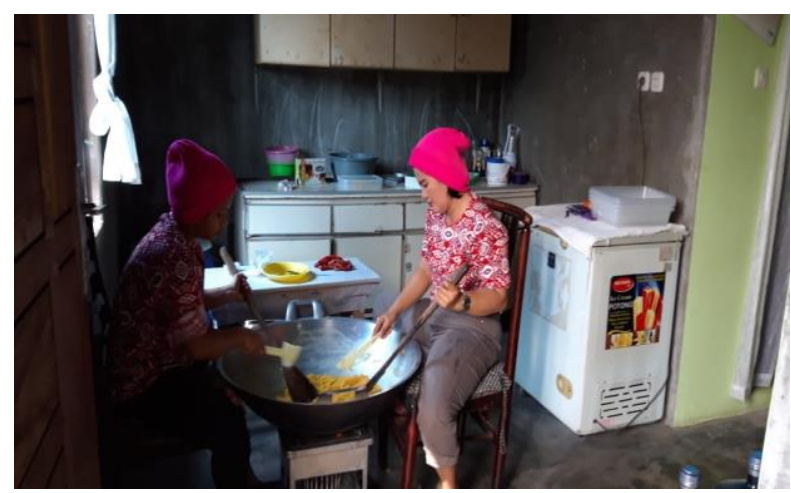

design thinking to improve psychological interventions: the case of the growth mindset during the transition to high school. Journal of Educational Psychology, 108(3), 274-391. https://psycnet.apa. org/doi/10.1037/edu0000098

Zuari, F. O., idayani, H., \& Daniel, R. D. (2013). Pengaruh strategi pemasaran terhadap penerimaan bersih restoran Omah Pincuk. Prosiding PESAT, 5, E383 -E389.

\section{Appendix B.}

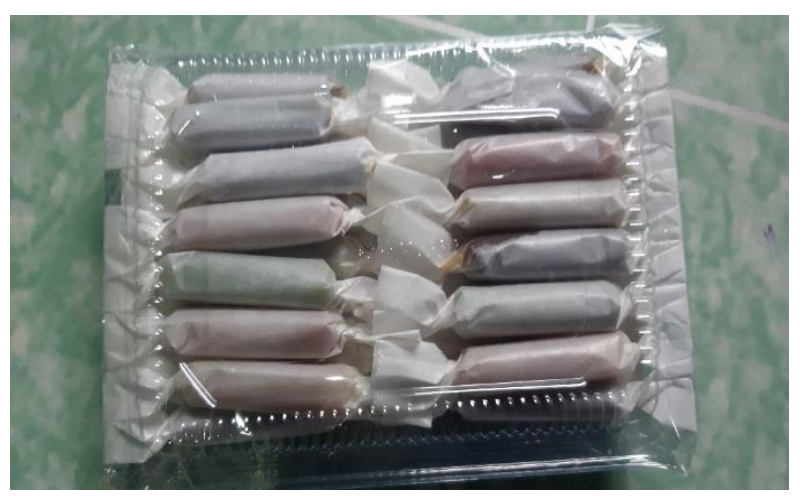

